\title{
EVALUATION OF THE IMPLEMENTATION OF THE 2013 CURRICULUM REVIEWED FROM THE ASPECT OF THE LEARNING PROCESS AND ASSESSMENT OF LEARNING OUTCOMES (Case Study: SMA/SMK/MA Pringsewu Regency)
}

\author{
Trisnawati, Leni Anggraeni, Winia Waziana, dan Dian Puspita \\ Information Systems Study Program, STMIK Pringsewu Lampung \\ e-mail: trisnawatistmikpsw@gmail.com
}

\begin{abstract}
This study aims to determine and evaluate the implementation of the 2013 curriculum specifically in aspects of the learning process and aspects of assessment of learning outcomes. This study is a qualitative descriptive study, with the population being SMA / SMK equivalent in Pringsewu Regency while the sample is 10 high school / SMK level schools in Pringsewu Regency selected from 9 different sub regency. In terms of the learning process aspect, achieving the highest percentage is the teacher's understanding of the subject matter in student textbooks, while the lowest percentage is the suitability of learning procedures with a scientific approach. In terms of the assessment of learning outcomes, the highest percentage achievement is the teacher's understanding of the concepts and applications of midterm tests, while the lowest percentage is the teacher's understanding of portfolio-based assessment concepts and applications. The results of the overall analysis show that, in terms of the learning process aspects and assessment of learning outcomes, the implementation of K-13 at the SMA/SMK/MA level in Pringsewu Regency was in a good category although there were still a few things that needed to be improved.
\end{abstract}

Keywords: evaluation, implementation, 2013 curriculum, learning process, assessment of learning outcomes

\section{EVALUASI IMPLEMENTASI KURIKULUM 2013 DITINJAU DARI ASPEK PROSES PEMBELAJARAN DAN PENILAIAN HASIL BELAJAR} (Studi Kasus: SMA/SMK/MA Kabupaten Pringsewu)

\begin{abstract}
Abstrak
Penelitian ini bertujuan untuk mengetahui dan mengevaluasi implementasi kurikulum 2013 khususnya dalam aspek proses pembelajaran dan aspek penilaian hasil belajar. Penelitian ini merupakan penelitian deskriptif kualitatif, dengan populasinya adalah SMA/SMK sederajat di kabupaten pringsewu lampung sedangkan sampelnya adalah 10 SMA/SMK sederajat di kabupaten Pringsewu Lampung yang dipilih dari 9 kecamatan yang berbeda. Ditinjau dari aspek proses pembelajaran, pencapaian persentase tertinggi adalah pemahaman guru tentang materi pelajaran yang ada di buku pelajaran siswa, sedangkan persentase terendah adalah kesesuaian prosedur pembelajaran dengan pendekatan saintifik. Ditinjau dari aspek penilaian hasil belajar, pencapaian persentase tertinggi adalah pemahaman guru tentang konsep dan aplikasi ulangan tengah semester, sedangkan persentase terendah adalah pemahaman guru tentang konsep dan aplikasi penilaian berbasis portofolio. Hasil analisis secara menyeluruh menunjukkan bahwa ditinjau dari aspek proses pembelajaran dan penilaian hasil belajar, implementasi $\mathrm{K}-13$ di tingkat SMA/SMK/MA di kabupaten Pringsewu berada pada kategori baik meskipun masih ada beberapa hal yang perlu diperbaiki.
\end{abstract}

Kata Kunci: evaluasi, implementasi, Kurikulum 2013, proses pembelajaran, penilaian hasil belajar 


\section{INTRODUCTION}

The curriculum in Indonesia has been developing since the period before 1945 to the 2006 curriculum which was valid until the end of 2012. The replacement of the curriculum aims to improve the quality of the learning process and learning design in schools. According to some experts, curriculum changes from time to time, both in Indonesia and in other countries, are caused by the needs of the people who are always developing every year and the demands of the times that tend to change. Curriculum development is considered as a determinant of the future of the nation's children. Therefore, a good curriculum will be highly expected to be implemented in Indonesia so that it will produce a bright future for the children of the nation which has implications for the progress of the nation and country. The 2013 curriculum has been implemented since mid-2013 but until now there are still pros and cons in implementing it. Even the implementation of the 2013 curriculum is still being reviewed and evaluated.

Based on PERMENDIKBUD number A 81 regarding the implementation of the 2013 curriculum, the 2013 curriculum was implemented in Indonesia starting the 2013/2014 school year. K-13 is a further step of KTSP which includes aspects of attitude, knowledge and skills in an integrated manner. Curriculum implementation is the activity of practicing/ implementing an idea, program or set of new activities for individuals or organizations that run the curriculum. This is consistent with the opinion of Majid (2014) which states that "curriculum implementation is the operation of curriculum concepts that are still potential (written) to be actually in learning activities. Implementation of the curriculum includes three main activities namely development programs, implementation of learning and evaluation of learning (Kunandar, 2013).

In the 2013 curriculum (K-13) for the high school level, there are 3 groups of subjects, namely groups A, B, and C. Group
A includes subjects in Religious Education, Pancasila and Citizenship Education, Mathematics, Indonesian History and English. Group B consists of subjects in Culture and Arts, Physical Education in Sport and Health, and Workshops. Group C is also called specialization subjects. Subjects included in this group for the specialization in Mathematics and Sciences are Mathematics, Biology, Physics and Chemistry. As for the social specialization groups are Geography, History, Economics, Sociology and Anthropology). The subjects in Specialization Language are Indonesian Language and Literature, Mandarin Language and Literature, English Language and Literature, and Arabic Language and Literature. There are also elective subjects consisting of other foreign languages, media literacy in applied technology and others.

All students are required to attend group $\mathrm{A}$ and $\mathrm{B}$ subjects and choose one group $\mathrm{C}$ (specialization). The learning time taken is 18 hours for compulsory subjects, 16 hours for specialization subjects and 6 hours for cross-interest subjects, elective subjects and additional elective subjects from school (Document K-13).

The evaluation has an important role in the implementation of the 2013 curriculum. Through this evaluation, the success and level of achievement of the program can be known. Evaluation results can also be used as a reference in determining policies related to curriculum follow-up because through evaluation it can be seen the condition of the curriculum in its design, implementation and results. Curriculum evaluation is intended to examine the level of achievement of educational goals that want to be realized through the curriculum concerned, work indicators to be evaluated are the effectiveness of the program (Syaodih, 2009).

The learning process in the 2013 curriculum is carried out through the Scientific Approach. In its implementation this approach emphasizes five important aspects, namely observing, asking, trying, 
reasoning and communication. These five aspects must really be seen in the implementation of learning in the schools. Students are required to be active, creative and innovative in problem solving. However, based on the results of the presurvey, the facts show that teachers still find it difficult to leave the old style, that is the teacher center learning model. Teachers still dominate learning activities in the classroom, while the 2013 curriculum expects students to be activated in learning activities, while teachers only act as facilitators, whose main task is to guide and direct students towards learning goals.

In the 2013 curriculum, assessment is obtained from all aspects. Taking students' scores is not only obtained from test scores but also from scores of politeness, religion, practice, and attitude and so on. Sudjana (2005) says that the assessment of learning outcomes is the process of assigning values to learning outcomes achieved by students with certain criteria. This implies that the object being assessed is student learning outcomes. Behavior as a result of learning in a broad sense covers the fields of cognitive, affective and psychomotor. Assessment and measurement of learning outcomes are carried out using tests of learning outcomes, especially cognitive learning outcomes about the mastery of teaching materials in accordance with educational and teaching objectives. Assessment of learning outcomes in the 2013 curriculum is still relatively new for teachers, causing many schools where teachers experience confusion in conducting assessments (Sutadji, 2014). Moreover, those who must report the assessment of learning outcomes are the teachers per subject itself. Teachers are also required to get to know students more deeply in order to be able to assess aspects of attitudes and skills.

Previous research conducted by Abrory \& Kartowagiran (2014), the results of the 2013 curriculum implementation research namely, the quality of syllabus planning and lesson plans in learning categories are good, the quality of learning implementation in preliminary activities, core activities, and closing activities are inferior, the assessment quality lessons included in attitude competencies, knowledge competencies, and knowledge competencies included in the unfavorable category. Then the research conducted by Meiana Yurike Dewi (2015), the results showed that Indonesian language teachers in the Bantul Regency High School implemented the 2013 Curriculum; The teacher's response to the 2013 curriculum is a good and ideal curriculum, but it is sudden and lacks preparation; obstacles in implementing the 2013 curriculum are time constraints, limited facilities and infrastructure, assessment, and student care in the teaching and learning process; The teacher overcomes obstacles in implementing the 2013 curriculum by giving home assignments, conducting group assessments, completing the administration of the teacher at home, using existing media and completing themselves, providing motivation and stimulation in the form of giving praise and adding value to students, assessments are carried out periodically and using MGMP forum as a place to exchange information.

Based on the above explanation, researchers are interested in conducting research with the title evaluation of the implementation of the 2013 curriculum in terms of aspects of the learning process and assessment of learning outcomes. The results of this study are expected to be beneficial as a positive contribution to curriculum development in the framework of applying the 2013 curriculum and are expected to be useful as study material or information for high school/vocational/MA teachers in Pringsewu Regency. This study aims to determine and evaluate the implementation of the 2013 curriculum specifically in aspects of the learning process and aspects of assessment of learning outcomes. For the school, the results of this study can be used as input to teachers and principals in relation to the learning process and assessment of student learning outcomes. 


\section{METHODS}

This research will be conducted in March - May 2019, the location of the study is a high school/vocational equivalent in Lampung Pringsewu Regency. This research is descriptive qualitative research which is one of the studies conducted with the aim to find a solution or a solution to the problem that occurs and then present the data and analysis of the information collected (Nazir, 2009). The object of research can be stated as a social situation of research that wants to know what is happening in it. On the object of this study, researchers can observe in depth the activities (activities) of people (actors) that exist in certain places (Sugiyono, 2007). The object of this research is the implementation of the 2013 curriculum for senior high school/vocational level in Pringsewu Regency. The tools used in this study include digital cameras, stationery, laptops, research questioners and vehicles for mobilization.

Population is a whole or a set of objects and subjects with the same characteristics (Singarimbun \& Sofian, 1989). The sample is a portion of the individuals investigated from the whole study individual. A good sample is a representative of the population or a representative meaning that describes the state of the population or reflects the population to the fullest. In this study, the population is SMA/SMK equivalent in Pringsewu Regency while the sample is 10 SMA/SMK equivalent in Pringsewu Regency selected from 9 different subregency areas. In this study data collection was done by observation, questionnaires, interviews and documentation.

This study use Quantitative and Qualitative Data analysis technique. Quantitative data obtained through the distribution of questionnaires will be analyzed using descriptive analytical methods by looking for descriptive percentages. Descriptive results of percentage data will be included in the answer category in order to obtain conclusions about each aspect analyzed.
The category response rates are shown in the following table 1 .

Table 1. Respondent Response Rate Category

\begin{tabular}{ccl}
\hline No. & Level of Answer Category \\
\hline 1 & $76 \%-100 \%$ & Very Good \\
2 & $51 \%-75 \%$ & Good \\
3 & $26 \%-50 \%$ & Poorly \\
4 & $1 \%-25 \%$ & Not Good \\
\hline
\end{tabular}

Qualitative data obtained through interviews and documentation. The data will be analyzed with the stages of reducing data, displaying data and drawing conclusions.

\section{RESULTS AND DISCUSSION}

\section{Learning Process Aspects}

Indicators of aspects of the implementation of the learning process in this study consisted of the teacher's understanding of the subject matter in student textbooks, the teacher's understanding of how to achieve spiritual (KI-1) and social (KI-2) competence in learning, the teacher's understanding of using a scientific approach, the suitability of learning procedures with a scientific approach, and the implementation of remedial learning and enrichment. The following are the results of the questionnaire results reviewed from each indicator in aspects of the learning process.

Table 2. Learning to Process Aspect Questionnaire Results each Indicator

\begin{tabular}{cccccc}
\hline $\begin{array}{c}\text { Indi- } \\
\text { cator }\end{array}$ & $\begin{array}{c}\text { Total of } \\
\text { Respondent }\end{array}$ & $\mathrm{n}$ & $\mathrm{N}$ & $\mathrm{DP}$ & Category \\
\hline 1 & & 280 & & $78 \%$ & $\begin{array}{c}\text { Very } \\
\text { Good }\end{array}$ \\
2 & & 276 & & $77 \%$ & Very \\
& 90 & & 360 & & Good \\
3 & & 262 & & $73 \%$ & Good \\
4 & & 246 & $68 \%$ & Good \\
5 & & 273 & $76 \%$ & Very \\
& & & & & Good \\
\hline
\end{tabular}


Information:

Indicator 1 : teacher understands of the subject matter in student textbooks

Indicator 2 : teacher's understanding of how to achieve spiritual (KI1) and social (KI-2) competence in learning

Indicator 3 : teacher understands of using a scientific approach

Indicator 4 : the suitability of learning procedures with a scientific approach

Indicator 5: the implementation of remedial learning and enrichment

The table will be clearer if presented in graphical form as follows:

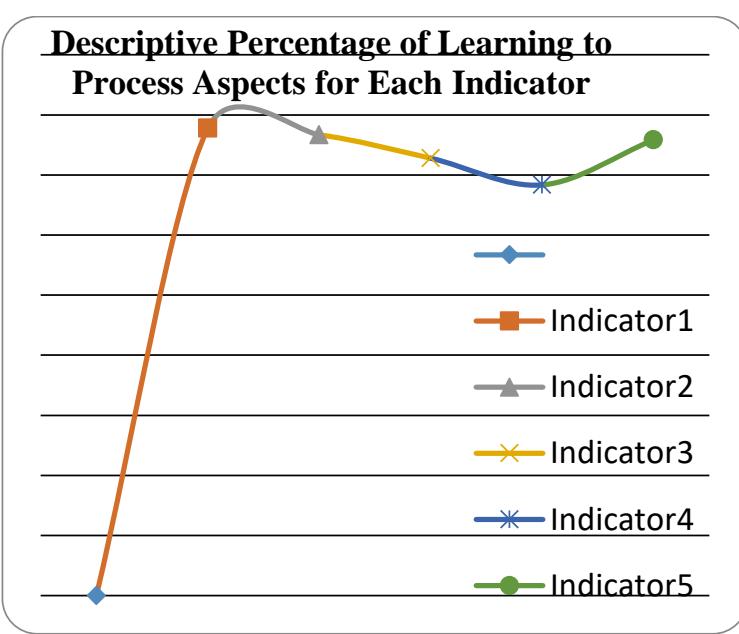

Figure 1. Descriptive graph of percentage of learning to process aspects for each indicator

Based on the graph, it is seen that the highest percentage achievement is the teacher's understanding of the subject matter in student textbooks, while the lowest percentage is the suitability of learning procedures with a scientific approach. After conducting interviews with school principals and teachers, they experienced difficulties in the scientific approach because they were new and could not be applied as a whole for all learning material.

Overall, the headmaster's perception, teacher's perception, and student's perception of the teaching and learning process K-13 obtained good results. Data obtained from the results of the questionnaire analysis can be seen in Table 3 below:

\section{Table 3. Learning to Process Aspect Questionnaire Results}

\begin{tabular}{|c|c|c|c|c|c|c|}
\hline No. & $\begin{array}{c}\text { Respon- } \\
\text { dent }\end{array}$ & Total & $\mathrm{n}$ & $\mathrm{N}$ & DP & Category \\
\hline 1 & $\begin{array}{l}\text { Head- } \\
\text { master }\end{array}$ & 10 & 151 & 200 & $75.50 \%$ & $\begin{array}{l}\text { Very } \\
\text { Good }\end{array}$ \\
\hline 2 & Teacher & 30 & 409 & 600 & $68.17 \%$ & Good \\
\hline \multirow[t]{2}{*}{3} & Student & 50 & 473 & 1000 & $47.30 \%$ & Poorly \\
\hline & Total & 90 & & & $63.66 \%$ & Good \\
\hline
\end{tabular}

Descriptive percentages filled by the principal amounted to $75.50 \%$, teachers amounted to $68.17 \%$ and the perception result of students was $47.30 \%$. After conducting interviews with students, the low percentage of descriptive to aspects of the learning process is due to the difficulty of students understanding the material because they have to study independently. According to them for some material, independent learning is not effective because students' reasoning sometimes does not arrive so that they have difficulty understanding the material. These results indicate that students follow the learning process despite being in the midst of various kinds of limited facilities and infrastructure in their respective schools. Apart from all this, it seems they are very eager to do something new especially something that is more prioritizing their interests.

Based on the results of the analysis of the feasibility of learning to use K-13 at the level of SMA/SMK/MA equivalent in ten (10) schools in Pringsewu regency an average of $63.66 \%$ was obtained. These results indicate that the learning process in Pringsewu regency using $\mathrm{K}-13$ is going well. Even so, from the results of the interview and filling out the questionnaire, there are several things that hinder the implementation of K-13, i.e.: Limited infrastructure, lack of student 
understanding about K-13 and the school environment that does not support the implementation of the desired learning process in K-13.

The solutions that researchers offer to overcome the obstacles that occur when implementing K-13 in the implementation of learning are: Teachers also maximize teaching and learning facilities available in schools by adding teaching aids or making teaching aids, and teachers adopt various learning approaches to create an atmosphere active learning so that the learning atmosphere is not saturated for students and students are more active in exploring information.

In the results of the analysis of the appropriateness and understanding of teachers towards K-13 show that Pringsewu Regency High Schools who have attended the training can be said to be capable and have good competence in carrying out teaching and learning processes based on $\mathrm{K}-13$. For teachers who have not had time to attend training or some teachers who have poor mastery, some obstacles faced are learning strategies due to limited infrastructure to implement K-13. Weaknesses are generally in the contextual development because it requires extensive teacher knowledge. Meanwhile, in general, the teachers still teach based on the textbook.

In addition to using the questionnaire, researchers also conducted interviews with 5 students in each school to find out students' responses regarding the learning process with the 2013 curriculum that they had been carrying out at school. One high school student in Pringsewu regency said that the 2013 curriculum is very good because students are taught to think more critically and objectively according to prescribed procedures. The same thing was conveyed by one of the vocational high school students in Sukoharjo sub regency, according to him, in the implementation of the 2013 curriculum, learning activities are not always in class, observation activities can be done outside the classroom and there are presentations and learning activities are certainly more exciting. While a different answer was given by one of the vocational students in Pagelaran Utara sub regency, according to him the 2013 curriculum was quite complicated because students made too many presentations, rarely recorded material, only given worksheets which then had to be collected again.

Based on the results of interviews conducted, there are a variety of different answers according to students' perceptions. Respondents (students) like the 2013 Curriculum learning style because learning varies, is not only theoretical and allows for learning. Meanwhile, according to Respondents (students) who do not like the 2013 Curriculum, they find it difficult to understand the material because they have to study independently.

2. Aspects of the Assessment Process Indicators of the assessment process in evaluating the implementation of K-13 in Pringsewu Regency are: teacher's understanding of the concept and application of daily tests, authentic assessment concepts and applications, selfassessment concepts and applications, portfolio-based assessment concepts and applications, and the concepts and applications of midterm tests. Following are the results of the questionnaire results in terms of each indicator in aspects of the assessment process.

Table 4. Assessment Process Aspect

Questionnaire Results each Indicator

\begin{tabular}{cccccc}
\hline Indicator & $\begin{array}{c}\text { Total of } \\
\text { Respondent }\end{array}$ & $\mathrm{n}$ & $\mathrm{N}$ & $\mathrm{DP}$ & Category \\
\hline 1 & & 119 & & $74 \%$ & Good \\
2 & & 120 & & $75 \%$ & Good \\
3 & 40 & 122 & 160 & $76 \%$ & Very \\
4 & & 116 & & $73 \%$ & Good \\
5 & & 135 & $84 \%$ & Vood \\
& & & & & Good \\
\hline
\end{tabular}


Information:

Indicator : teacher understands of the concept and application of daily tests

Indicator 2 : authentic assessment concepts and applications

Indicator 3 : self-assessment concepts and applications

Indicator 4 : portfolio-based assessment concepts and applications

Indicator 5: the concepts and applications of midterm tests

The table will be clearer if presented in graphical form as follows:

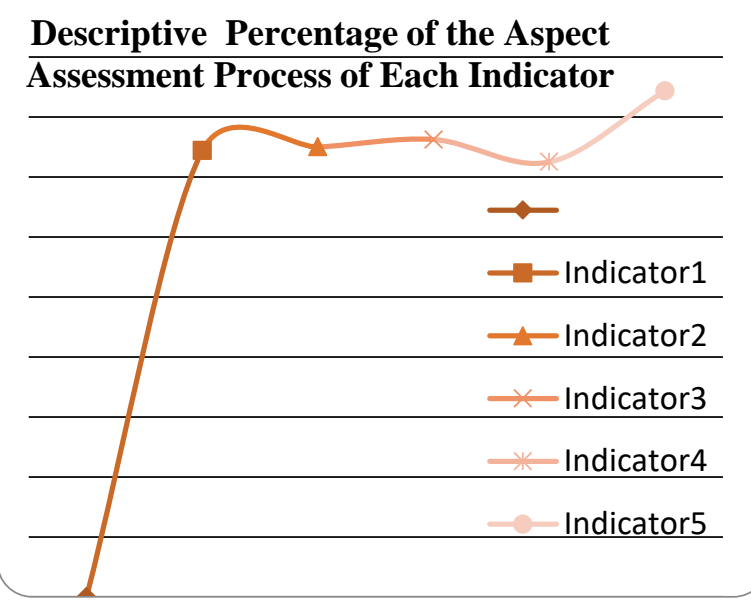

Figure 2. Descriptive graph of the percentage of the aspect assessment process of each indicator

Based on the graph, it is seen that achieving the highest percentage is the teacher's understanding of the concepts and applications of midterm tests, while the lowest percentage is the teacher's understanding of portfolio-based assessment concepts and applications. After conducting interviews with school principals and teachers, they experienced difficulties in the concept and application of portfolio assessment because so far (the old curriculum) the assessment had never been carried out. During the training on the 2013 curriculum, there were no concrete examples of the application of portfolio assessment in learning activities.

Overall the headmaster's and teacher's perception of the teaching and learning process $\mathrm{K}-13$ for the assessment aspects of learning outcomes obtained good results. Data obtained from the results of the questionnaire analysis can be seen in Table 5 below:

Table 5. The Results of the Questionnaire Aspects of the Assessment Process

\begin{tabular}{clccccc}
\hline No & Respondent & Total & $\mathrm{n}$ & $\mathrm{N}$ & $\mathrm{DP}$ & Category \\
\hline 1 & Headmaster & 10 & 153 & 200 & $76.50 \%$ & $\begin{array}{l}\text { Very } \\
\text { good }\end{array}$ \\
2 & Teachers & 30 & 424 & 600 & $70.67 \%$ & Good \\
& Total & 40 & & & $73.58 \%$ & Good \\
\hline
\end{tabular}

Based on the results of the calculation of the questionnaire data in table 5 above, that percentage of teachers' perceptions of assessment is $70.67 \%$ this is a good category. While from the results of the questionnaire data that was distributed to the headmaster, the perception of the assessment process was obtained by a percentage of $76.50 \%$. The average obtained from filling out the questionnaire by the headmaster and teachers related to aspects of the process of evaluating the implementation of $\mathrm{K}-13$ at the SMA/ SMK/MA level in Pringsewu Regency was $73.58 \%$. These results refer to both categories in the aspect of the assessment process.

Here we see the result of the interview aspects of the assessment becomes difficult for some teachers in the implementation of $\mathrm{K}-13$ at the level of SMA/SMK/MA Pringsewu Regency. The reason is the lack of training on the aspects of appraisal and too many appraisal formats in appraisal applications. The assessment process in $\mathrm{K}-13$ is felt to be more difficult and complicated. The results of the interview clearly illustrate that the assessment aspect became difficult for teachers in implementing $\mathrm{K}-13$ in Pringsewu Regency. The reason is the lack of training in the aspect of training and too many assessment formats in the assessment application. The assessment process in $\mathrm{K}$ 13 feels more difficult and complicated, but many teachers are optimistic that they can carry out assessments well. 
In general, the obstacles faced by teachers in the assessment standards are as follows: The teacher does not understand well the authentic assessment model because the filling method is felt to be a burden on the teacher and many rubrics that must be filled. The authentic assessment used in K-13 consists of an assessment of spiritual and social attitudes, an assessment of skills and an assessment of knowledge. The task of the teacher is tougher and requires accuracy in getting to know students one by one, it cannot be classically. Many things that make teachers experience obstacles namely aspects of attitude assessment that has several elements, for example, the value of discipline, cooperation and an attitude of respect for the opinions of others, etc. In addition, in terms of skills as well, teachers must conduct observations and portfolio assessments. Assessment in the aspect of knowledge is done by understanding, understanding and being able to present, there is a value of percentage and assessment of tasks.

Efforts that can be made to overcome the obstacles experienced by teachers in terms of assessing students is very necessary discussions for teachers in overcoming the problems they face. In this way, the teacher can exchange ideas and help each other so that the teacher who does not know can know in making a correct assessment. This discussion forum can be held during the Subject Teachers' Meeting (MGMP), so that this MGMP can be an alternative for teachers in overcoming the problems faced.

\section{CONCLUSION}

Based on the research results of the 2013 curriculum implementation evaluation in terms of aspects of the learning process and assessment of learning outcomes it can be concluded that Judging from the aspects of the learning process, the implementation of K-13 at the SMA/SMK/MA level in Pringsewu Regency is in the good category with a level of achievement of $63.66 \%$ and Judging from the aspects of the assessment of learning outcomes, the implementation of K-13 at the SMA/SMK/MA level in Pringsewu Regency is in the good category with a level of achievement of $73.58 \%$. Based on the research results, the researcher can give some suggestion i.e. headmaster must improve coordination with all K-13 implementer teachers, school committees, supervisors, and parents to overcome obstacles in implementing K-13. Then the teachers and students should be more proactive in knowing concepts and techniques regarding the implementation of $\mathrm{K}-13$.

\section{ACKNOWLEDGMENT}

Alhamdulillahi Rabbil 'Alamin, the researcher expresses his highest gratitude to Allah Subhanahu Wa Ta'ala for blessing love, opportunity, health, and mercy to complete the journal with the title: Evaluation Of The Implementation Of The 2013 Curriculum Reviewed From The Aspect Of The Learning Process And Assessment Of Learning Outcomes.

This research was supported by DRPM KEMENRISTEKDIKTI. We also thank to Dr. Abdul Hamid, M.Pd.I. as chairman of the STARTECH Education Foundation, Sri Hartati, as chairman of STMIK Pringsewu Lampung Indonesia, LPPM of STMIK Pringsewu Lampung, and our colleagues who provided insight and expertise that greatly assisted the research. Finally, we would like to thank everybody who was important to the successful realization of this journal. This journal is far from perfect, but is expected that it will be useful not only for the researcher, but also for the readers. For this reason, constructive thoughtful suggestion and critics are welcomed.

\section{REFERENCE}

Abrory, M dan Kartowagiran, B. (2014). Evaluasi Implementasi Kurikulum 2013 pada Pembelajaran Matematika SMP Negeri Kelas VII di Kabupaten Sleman. Jurnal 
Evaluasi Pendidikan - Volume 2,

No 1

Dewi, M. Y. (2015). Implementasi Kurikulum 2013 Pada Mata

Pelajaran Bahasa Indonesia di SMA

Negeri Kabupaten Bantul

Yogyakarta. Yogyakarta: UNY

Kunandar. (2013). Penilaian Autentik. Jakarta: Raja Grafindo Persada

Majid, A. (2014). Implementasi Kurikulum 2013 Kajian Teoritis dan Praktis. Bandung: Interes Media

Mendikbud. (2013). Dokumen Kurikulum 2013 (Draf). Jakarta: Kementerian Pendidikan dan Kebudayaan

Nazir, M. (2009). Metode Penelitian. Bandung: Remaja Rosdakarya

Singarimbun, M., dan Sofian, E. (1989). Metode Penelitian Survai. Jakarta: LP3ES

Sudjana, N. (2005). Dasar-dasar Proses Belajar Mengajar. Bandung: Sinar Baru Algesindo.

Sugiyono. (2007). Metode Penelitian Kuantitatif Kualitatif dan $R \& D$. Bandung;Alfabeta

Sutadji, E. (2014). Pengukuran Hasil Belajar Siswa Sekolah Menengah Kejuruan: Tantangan Tenaga Pendidik dalam Melaksanakan Penilaian Menurut Kurikulum 2013. Prosiding, Konvensi Nasional Asosiasi Pendidikan Teknologi dan Kejuruan. Bandung: Universitas Pendidikan Indonesia. Diakses dari www.jurnal.upi.edu.

Syaodih, N. (2009). Pengembangan Kurikulum. Bandung: PT Remaja Rosdakarya. 